\title{
Gene transfer makes a start
}

\section{Savannah, Georgia}

ONE reflection of the rapid growth of plant molecular biology is that it is now possible to attract some 1.800 participants to one of those unwieldy international symposia whose concurrent sessions occupy the ballrooms of the larger hotels in out-of-season resorts. The International Society for Plant Molecular Biology at any rate regards its congress held here last week as a milestone in the field.

Although the use of recombinant DNA to transfer genes between plants may eventually change the face of the Earth, to judge from last week's scientific presentations, its principal impact in the immediate future is likely to be on the fortunes of the agrichemical industries that support much of the basic research. Only two weeks ago, a team from Calgene reported (Nature 317,$741 ; 1985$ ) the introduction into a tobacco plant of a bacterial gene conferring resistance to the Monsanto herbicide glyphosate; similar results were reported here by Rob Fraley (from Monsanto's own laboratories working in collaboration with Nam-Hai Chua and colleagues at Rockfeller University), but with a plant gene and in tomato as well as tobacco and petunia.

Glyphosate is an indiscriminate herbicide that destroys crop plants and weeds alike, and whose use is therefore confined to ground clearance. Glyphosate tolerance into crop plants would thus greatly extend the application of the chemical.

But this is not the sole, or probably even the principal, reason for the impressive advances in the manipulation of herbicide resistance. Analogous experiments were reported by Lawrence Bogorod (Harvard) with a gene for the Ciba-Geigy herbicide atrazine, which is now out of patent and so no longer of compelling commercial interest. The attraction is that the genetic and biochemical basis of herbicide tolerance is both relatively simple and extremely well understood. Most broadly desirable genetic assets, such as the ability to resist pathogens or fix nitrogen are complex and relatively ill-understood. In pathogen resistance, pathogens seem capable of producing virulent mutants about as fast as molecular biologists can engineer plants to resist them. Herbicides are an easier target.

Among other sobering considerations offered in a presentation by M.S. Swaminathan, director of the Institute of Rice Research in Manila, is that the basic genetics of Third-World staples such as rice are in such a primitive state that they have simply not been accessible to molecular manipulation. A further difficulty is that rice, like other cereals, is a monocotyledon. So far, the recipes for regenerating complete plants from manipulated cells will work only for dicots, whence the con- centration on tobacco, petunias or, at best, tomatoes.

Nevertheless, the Rockefeller Foundation is supporting a campaign on the rice genome which, with the use of the molecular mapping techniques that have been so successfully exploited in the analysis of human genetic disease, should be reasonably well charted within a year or so. Progress on regenerating genetically engineered plants is less predictable (tissue culture is still largely a black art) but two speakers at Savannah reported a significant step forward. Genes artificially introduced have not in the past functioned stably in cultured cells from monocotyledons, but this has now been achieved in maize (Michael Fromm, Stanford) and Italian rye grass (Lawrence Potrykus, Friedrich Miescher Institute). The next step is to persuade the cultured cells to regenerate into a complete plant, which many believe will be a matter chiefly of luck and patience.

Meanwhile. new techniques for gene transfer based on electroporation (which allows DNA to enter cells exposed to strong electric fields) are helping molecular biologists to identify and isolate the genetic control elements that determine the responses of plants to the critical features of their environment. The DNA elements that enable genes to be activated by heat and light have already been identified; Jim Peacock reported that his group at the Commonwealth Scientific and Industrial Research Organization in Canberra now has a gene that controls the induction of others in anaerobic conditions. In principle, these genetic control elements could be manipulated to increase the resistance of crops to natural disasters such as drought. How it will be in practice, and when, it is too soon to guess. Even resistance to herbicides is not yet ready for the field. Miranda Robertson

\section{Space insurance}

\section{Market confident of survival}

\section{Washington}

US GOVERNMMENT intervention to provide emergency insurance cover for commercial space ventures would be disastrous. Witnesses from the National Aeronautics and Space Administration (NASA), insurance companies and satellite manufacturers all agreed on this point when telling Congress last week how to prevent a space insurance crisis; more than $\$ 600$ million has been lost by insurers in the past 21 months, threatening the much vaunted commercialization of space.

James Barrett of Intec (International Technology Underwriters) is confident that market forces will prevail and allow the insurance industry to continue to "facilitate, but not subsidize" commercial space projects. He suggests spreading the load of space insurance risks throughout many smaller companies, which could support an "insurance pool" dedicated to space shuttle launches and cargoes. $\mathrm{He}$ also feels that the manufacturers should take more of the risk for the functioning of their products, which would doubtless improve reliability. Barrett is opposed to the sort of competition that is occurring at the moment between Arianespace and NASA; because Arianespace provides guaranteed launch insurance at belowmarket rates, NASA is planning to offer cut-price relaunches to customers whose satellites have failed within a given timespan. Such deals will deprive the insurance industry of premium revenue and inhibit the spread of risk, according to Barrett.

Jack O'Brien, NASA's general counsel, agrees that the market will stabilize without government intervention. NASA atready helps its smaller customers by waiving liability for small self-contained payloads so that the only loss the experimenters face is the face value of the project. NASA also disallows claims against each other by participants in a particular flight, and includes itself in this ban. It is carrying out a further evaluation of its risk allocation policies, but wants to find a solution in conjunction with the insurance industry that does not open the door for government regulations.

Predictably, the manufacturers themselves do not want to be liable for any loss risk. Charles Schmidt of RCA AstroElectronics says that the fiercely competitive business leaves no room for such guarantees. Smaller companies would lose business if a "no insurance, no financing" policy were introduced. One compromise would be for the industry itself to form a last-resort pool.

The message to the government from the construction industry and the insurers alike is clear - the market will look after itself. The satellite industry was so successful in the first ten years of its existence that insurers have grossly underestimated the cost of risks, leading directly to the present crisis. Underwriters are convinced that the pendulum will swing back and that a stable compromise can be reached if the government will give them time. In a country where space is taken so seriously that the normally conscientious chairman, Bill Nielson (Democrat, Florida), of the committee taking last week's evidence was absent because he is in training for the next shuttle flight, the commercial space industry had better make sure it has reason for its confidence that a solution can be found.
Maxine Clarke 